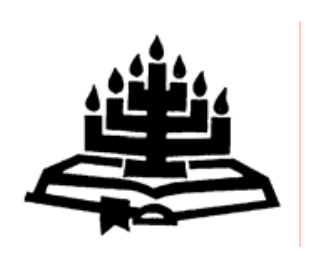

\title{
Covenant on Economic, Social and Cultural Rights - ethically evaluated
}

\author{
Herm J.G. Zandman \\ Covenant College \\ ACT Australia \\ E mail: zandman@ozemail.com.au
}

\begin{abstract}
Covenant on Economic, Social and Cultural Rights ethically evaluated
\end{abstract}

This article considers the ethical difficulties presented by the United Nations "Covenant on Economic, Social and Cultural Rights". Initially, the Biblical principles regarding entering into covenant are elucidated. Next, the United Nations' role in initiating global covenants is investigated in terms of what this body premises its mandate on. To follow is this particular covenant, presented as a case study. The weakness in the United Nations' approach to treaties and covenants is that the bedrock on which such covenants is being established is notably and necessarily absent. This means that terminology, phrases and application ipso facto are determined on the basis of human presuppositions, rather than on the metaphysically implanted principles of God. Herein lies the basic flaw to what appears on the surface to be a noble approach. In a global setting, with many different worldviews elbowing for room, harmonised application of generically applauded concepts is difficult. The moment a generic concept such as "freedom" needs to be handled, it becomes value-laden. The question is then by whose values this concept is going to be handled. Usually, when consensus cannot be reached, majority will rule. This means that the very sovereignty of member states, supposedly safeguarded in the covenant, is being eroded. For Christians, majority rule is not an acceptable modus operandi. The Christian would support the principled approach to ethical issues. However, where the ethical basis is not articulated, the plethora of opinions (collective or individual) is left to act by. This creates a difficult political environment, for which a solution is hard to find. Yet, the Christian must continue to strive to 
honour his Lord by striving to be "light and salt" in this political scene.

\section{Opsomming}

\section{Verdrag vir Ekonomiese, Maatskaplike en Kulturele Regte - eties beoordeel}

Hierdie artikel neem die etiese probleme in ag wat voorkom in die Verenigde Volke se "Verdrag vir Ekonomiese, Maatskaplike en Kulturele Regte". Eerstens word lig gewerp op Bybelse beginsels betreffende die deelname in 'n verdrag. Daarna word die rol wat die Verenigde Volke in die totstandkoming van globale verdrae gespeel het, ondersoek in terme van die grondslae wat die organisasie toeëien vir hulle mandaat. Vervolgens word 'n studie gemaak van hierdie spesifieke verdrag. Die swakheid in die Verenigde Volke se benadering van ooreenkomste en verbonde is dat die grondslag waarop genoemde verbonde bevestig word, pertinent en doelbewus weggelaat word. Dit beteken dus dat die terminologie, uitdrukkingswyse en toepassings ipso facto bepaal word op grond van menslike voorveronderstellings in plaas van op metafisies bepaalde beginsels van God. Hierin lê die basiese gebrek wat, oppervlakkig beskou, lyk of dit 'n edel benadering kan wees. In 'n globale raamwerk met verskillende wêreldbeskouings, wat elkeen streef om aanvaar te word, is die harmoniese toepassing van generiese prysenswaardige konsepte baie moeilik. Sodra oor 'n generiese konsep soos byvoorbeeld "vryheid" besin moet word, handel dit dadelik oor 'n waardeskatting. Die vraag ontstaan dus volgens watter waardes hierdie konsep beskou moet word. Gewoonlik, wanneer geen eenstemmigheid bereik word nie, word die meerderheidsoortuiging aanvaar. Dit beteken dus juis dat die veronderstelde versekerde soewereiniteit van ledestate wat veronderstel is om in die verbond verseker te wees, ondermyn word. Vir gelowiges is meerderheidsbeheer nie 'n aanvaarbare modus operandi nie. 'n Gelowige sal 'n prinsipiële beoodeling van etiese geskilpunte ondersteun. Waar die etiese basis nie duidelik bepaal is nie, bly daar net 'n verskeidenheid persoonlike opinies (kollektief of individueel) oor waarvolgens geoordeel kan word. Hierdeur word 'n situasie geskep waarvoor ' $n$ oplossing nie maklik gevind kan word nie. Die gelowige moet tog voortdurend poog om die Here te eer deur sy strewe om "lig en sout" te wees in enige staatkundige situasie.

\section{Introduction}

Humanists holding varying philosophies have unsuccessfully tried to find a basis for morality, trying to produce a decent, moral life in this 
world while denying the basis of morality in the being of God (Gresham Machen, 1982:27). In a world increasingly marked by global engagement in treaties, political covenants are - rightly drawn up to provide good structure and to ensure as high a measure of integrity in dealing with each other as possible. The answer of Desmond Tutu, given from his religious presupposition, is that religion should produce peace, reconciliation, tolerance, and respect for human rights. He reminds the reader that the parliament of World Religions during its 1995 meeting in Chicago concluded that there would be no new global order unless there was first a global ethic, which would be a fundamental consensus concerning binding values, irrevocable standards, and personal attitudes (Tutu, 1996:xv-xvi).

It is problematic to find an unifying basis of ethics because of the multifaceted standards that are brought to bear on international covenants, standards derived from various religious and cultural imprints as delegates meet to hammer out a covenant acceptable to all concerned. This problematic character as the Christian would perceive it, stems from the fact that according Scripture, ethics are theonomic, determined not by the self, but by the Lord who alone provides the absolutes for our relational conduct (Sproul, 2006:2930).

Any thoughtful observer who surveys the human rights scene around the globe today cannot help but notice how central the religious dimension is. Religious approaches would find scholars and diplomats suspending disbelief in the presence of homo religiosus. They would take seriously the claims of individuals and groups to be grounded in "ultimate concern" and to see their individual and group identity issuing from response to myths and symbols, rites and ceremonies, metaphysical claims and behavioural correlates of that concern (Marty, 1996:1, 4). A democratic process presupposes civic virtue; yet, much of what is undertaken is marked by what the parties hold as values. The objective standards of morality as inherited through JudeoChristianity are fading in the mêlée of ethical approaches derived from a multitude of worldviews. Where virtues fall away, they are generally replaced by some form of legal or political coercion (Weeks, 2005:v).

The making - or cutting - of a treaty is, in terms of its principles, a creational issue, going beyond the church; God established the principles of relational dealings for all of mankind, as made clear in the fact that the approaches were not only familiar to Israel, but to 
many of the surrounding cultures (McCarthy, 1978:52 ff.). Yet, the challenge of diversity needs addressing and it needs to be recognised that the answer is very difficult. People and communities live in and develop what phenomologist Alfred Schutz calls different "universes of discourse". These include, besides religion, universes related to race, ethnicity, tribe, gender, class, culture, aesthetics, or national experience (Marty, 1996:7). The disparity between religions is the most unsurmountable in this list to address, because religion addresses the most profound and fundamental four questions of life: those regarding ontology, axiology, teleology and epistemology. The conclusions of believers are deemed nonnegotiable, because of their transcendent and absolute source (Marty, 1996:9). This gainsays the view stated by Gabriel Marcel that "the validity of a belief consists in the fact that it expresses my actual being; my subjective reality" (in his essay on The phenomology and dialectic of tolerance, quoted from Marty, 1996:13). The Bible-believer will claim that my actual being is expressed in an objective reality, formed by the theonomic ethics supplied by God. Historically, and in the present day, religious activists have, on that basis, striven to establish a theocratic society by enforcing theocratic law. This leads to tension when involvement is invited in forming global covenants (An-na'im, 1996:338). Nevertheless, also those not classed as religious activists but holding firmly to ethical presuppositions, experience difficulty as non-negotiability drives wedges where and when collaborative models are being sought (Marin-Guzman, 2003; Stackhouse \& Healy, 1996:508-512). The ontological dignity of man is not at issue here, but the manner in which people with different ethical approaches are to work intimately together on a mondial scale in the context of rights issues that are, of necessity, differently perceived by the interest groups involved (Marty, 1996:6-16).

In the subsequent section of this article, the intent is to demonstrate what the approach to treaties ought to be according to the Biblical worldview and, once that has been established, to consider the value of one particular treaty which has been established under supervision of the United Nations. In view of the fact that treaty principles are creationally ordained as part of expressing human relationships, the aim will be to ascertain to what extent this particular mondial treaty, set among and subscribed to by a large diversity of peoples, is marked by these creation principles and worthy of note for Christian interest groups in terms of support and promotion. To establish this, the treaty will be viewed regarding what it aims to do, and how realistic its expectations are in terms of the Biblical worldview principles. It is being foreshadowed here that this 
covenant has a decidedly serious problem in terms of the commonly desired aims and (the absence of) a foundational framework. The conclusion of this writing will argue the nobility of expressed desire, the difficulty regarding fulfilling the aims, the cause for the difficulty, and the necessary implements to bring about better realisation of the aims stated in the document.

\section{Biblical approaches to treaties}

In terms of ethical approaches to treaties, there is a considerable difference between one who begins his or her reflection starting from the theme of religious rights along with other human rights, and one who begins his or her reflection starting from the theme of the religious source of rights which must consider the question of rights from more than just a human perspective. In Judaism, Christianity, and Islam, which are religions of revelation, each of them sees its own truth as coming from God, not man (Novak, 1996:175). As this writing approaches the treaty idea from the Biblical worldview perspective, it follows that the basis is that all truth is God's truth and thát exclusively. Therefore, the ethical approach for entering into covenants is determined by Biblical principles.

When considering the ethical approach to treaties, the perfect example of God in his dealings with mankind and the principles $\mathrm{He}$ laid down for his people in making treaties, provide guiding principles for men when entering into covenants.

First of all, when making an agreement with others, the agreement is to be total; half-heartedness is out of the question. This was understood with the holistic ritual implemented by the easterners of literally "cutting a covenant" (kārat $b^{e}$ rit) as they committed their entire persons and all they represented to the treaty by walking between the pieces of an animal that had been cut up (Douglas et al., 1982:240). In Genesis 15:17 God Himself utilises this principle as He covenants with Abram. The Apostle Paul writes about Jesus Christ, God the Son that $\mathrm{He}$

Who, being in the form of God, thought it not robbery to be equal with God: but made Himself of no reputation, and took upon Him the form of a servant, and was made in the likeness of men: and being found in fashion as a man, He humbled Himself, and became obedient unto death, even the death of the cross (Phil. 2:6-8, KJV).

This was the ultimate seal on the treaty which God made back in Genesis with his friend Abram. The treaty approach shows all the 
hallmarks of self-denying commitment. Here is the pattern for Christians.

Secondly, the person's integrity and that of his group was placed at the centre of dealings. As imagebearer of God, i.e. as one able to respond to God's commandments with a sense of authentic obligation (Novak, 1996:184), he would put his very essence, all which gave him dignity, on the line, declaring he would be worthy of annihilation should he break the agreement (Palmer Robertson, 1980:4-5).

In the third place, a treaty as intended by God is to be marked by selflessness (Douglas, 1982:240). In an ethically sound environment, an environment dictated by Biblical principles (Sproul, 2006:29-30), this ought to be the case.

With regard to human society, another principles-undergirded, historic thread may guide the Christian in approaching covenants or treaties, namely the manner in which God defined the nature of kingship in Israel. In the definition of godly kingship the principle of self-denial on behalf of others involved in relational interaction, often culminating in treaties, is made clear (Douglas et al., 1982:240, 655).

The question is now whether people in general, and Christians in particular, over the course of history have shown a grasp of this selfless principle, this agape love, that ought to make for wholesome and godly treaties. Note also that the Biblical examples of king David and Christ (cf. Deut. 17) concern not mere individuals, but rather representations of interest groups, of the body to which they are related. It is important to recognise this, because it is what establishes the link between the principles of Scripture and the situations which surround the creation of treaties at United Nations level.

Finally, there is one more aspect to consider when dealing with covenants in the Biblical context. When the matter of unification under an intimate covenant is considered, God makes it very clear how important ethical oneness is (Marin-Guzman, 2003; Stackhouse \& Healy, 1996:508-512). If the bedrock is of mixed substance, the superstructure tends to fail. The destructive influences of mixing Israel's religion with that of its neighbours bear testimony to this (cf. 1 Kings 11). 


\section{The United Nations' role in establishing treaties}

A priori, it is helpful to state that the concepts of rights can only correctly be understood in correlation with the concept of duty. In democratic societies, it is usually assumed that rights entail duties. That is, human persons as individuals have inherent needs and powers. Thus, in this view, individuals entitle the right of society to command its own duties in the form of public law, i.e. social duties are justified by individual rights. However, in the context of Biblical approaches, this social contract theory assumes that the human individual is sovereign rather than God. Biblical covenant making is done within a system where duties are correlative with the supreme rights of God the Creator. Often the role played by teleology in human rights and the shaping of covenants is ignored, and when it is treated, it usually compromises the deontological character of rights (Stackhouse \& Healy, 1996:512). There is a symbiotic relationship (Novak, 1996:179-180) between rights and duties (with duties being emphasised Scripturally, as these must always necessarily be exercised upon the rightful recipients).

Also the preamble of the United Nations Charter (Anon., 1945) may be regarded as a duty statement towards rightful recipients:

We, the people of the United Nations determined to save succeeding generations from the scourge of war, which twice in our lifetime has brought untold sorrow to mankind, and to reaffirm faith in fundamental human rights, in the dignity and worth of the human person, in the equal rights of men and women and of nations large and small, and to establish conditions under which justice and respect for the obligations arising from treaties and other sources of international law can be maintained, and to promote social progress and better standards of life in larger freedom, and for these ends, to practise tolerance and live together in peace with one another as good neighbours, and to unite our strength to maintain international peace and security, and to ensure, by the acceptance of principles and the institution of method that armed force shall not be used, save in the common interest, and to employ international machinery for the promotion of the economic and social advancement of all peoples, have resolved to combine our efforts to accomplish these aims. Accordingly, our respective Governments, through representatives assembled in the city of San Francisco, who have exhibited their full powers found to be in good and due form, have agreed to the present Charter of the United Nations and do hereby 
establish an international organization to be known as the United Nations (Anon., 2005).

This preamble declares that the collective membership of the United Nations is committed to arriving at agreements which are intended to serve the good of mankind by doing the following:

- protecting fundamental human rights;

- affirming and promoting the actualisation of the dignity and worth of every person;

- affirming and promoting the, at least, ontological equality between men and women;

- working toward the acknowledgement of equal rights of independent nations, regardless of size, in the global scene of events;

- just implementation of agreed-upon treaties;

- use of force only if it serves the common interest;

- promotion of peace and tolerance between (political) neighbours;

- employment of international machinery, including judicious use of armed forces, to maintain international peace and security.

This, on the surface, laudable preamble, appears to be fraught with much difficulty. Were such a preamble written in a document of the Reformed Churches, then all the clauses would be understood within the framework of Scripture and the confessions. The context would clarify the particular terminology. However, with the vast variety of ideological participants in the United Nations membership, such a unifying framework is - and must be of necessity be absent. Stackhouse and Healy claim that, despite the fact that the issue is fraught with tension and difficulty, a unifying ethos can be arrived at (Stackhouse \& Healy, 1996:508-516), but they also quote many sceptics contesting that stance. These sceptics basically hold that the fundamental differences will always continue to drive divisions.

At the 2005 Values Education Symposium in Canberra, Australia, emeritus-professor Ivan Snook spoke some words of warning in a similarly sceptical manner:

Every one will agree that it is a good thing to promote 'compassion'. Let it be known, however, that such a concept 
starts to bite hard when it comes to practical application. It is at that point that applicatory meaning needs to be given to this beautiful, presently abstract concept (Snook, 2005).

The speaker made a good point: compassion can translate into different things for different people, depending on adopted ethos.

In the context of human covenants, it will be necessary to establish what the basis is for human rights colouring them. The content is determined by presuppositions held. Human rights of women translate quite differently in Western society than they do in Eastern society (Wadud, 2002). Dignity and worth of people has largely been reduced to economic value in Western society. The Judeo-Christian concept of humanity spawned unique advances in human rights and respect for the human person. Inalienable rights, prohibitions of torture, church-mandated protection of civilians in war, acts of mercy, exalting of the poor and downtrodden, and respectful treatment of the dead are all descendants of Genesis. Today, the traditional image of the human body has been shattered (Herman, 1992:32; Kimbrell, 1993:234-237). Over the last centuries, and increasingly in recent years, our understanding and view of man has undergone a conceptual free-fall as advances in science and technology appear to confuse and obscure any fixed definition of human life. Gradually, the body as sacred has evolved into the body as secular. The body is no longer seen as analogous to the divine, but rather as similar to the engines of industry (Kimbrell, 1993:233). The level of sacredness attributed to man colours the interpretation of covenants between men.

It is on this basis, what the view of man is in the first place, and that all the points of the United Nations Charter Preamble must be interpreted. As the view of man differs according to the religious and cultural background of the signatories to the covenant under study, the resultant outworking will cause tension (Stackhouse \& Healy, 1996:508-512). The fact that much of Western thinking nowadays is influenced by the deconstructive approach - a way of reading and interpreting writings from the reader's viewpoint rather than from the viewpoint intended by the author - developed and promoted by Michel Foucault and Jacques Derrida (Honeysett, 2002:23-49), makes unified understanding and application all the more problematic. 


\section{Case study: International Covenant on Economic, Social and Cultural Rights}

This treaty came into force on 3 January 1976. Its aim is clear from the title, namely, to ensure that people everywhere are ensured the right to material adequacy, relational meaningfulness and the right to express particular, unique cultural identity without fear of discrimination, vilification or persecution. Regarding material, emotional, relational and - when considering cultures - spiritual impact, this treaty is among the most-encompassing ones in existence, hence its selection for this article. The length of this covenant, 39 articles, prevents exhaustive analysis of every detail, but the sections selected for scrutiny are representative of the others, in that the absence of a clearly defined, presuppositional framework renders definitive, uniform understanding difficulty.

In its preamble, justification for the aims is found in the Charter of the United Nations, with recognition of the inherent dignity and the equal, inalienable rights of all members of the human family resulting in freedom, justice and peace throughout the world. This statement is basically a summary of articles 1 and 12 in the Universal Declaration of Human Rights. The concept of freedom is defined and described further down in the preamble as being "freedom from fear". The collective striving is to establish an environment in which man, individually and collectively, may be assured that he has the opportunity to unfold his human dignity without destructive influences hampering such unfolding.

Considering the concept of "rights", mentioned in the first paragraph of this case study, we may conclude with Calvin (Baillie et al., 1979:1520) that everything ecclesiastical, social and political should be founded in the sovereignty of God, not in the sovereignty of man (Vorster, 2004:42). Calvin makes clear that there is an inextricable relation between the responsibilities and rights of people, resulting it the right to spiritual liberty, political liberty, religious liberty and the liberty to resist oppressive civil authority (Vorster, 2004:42). If this covenant were founded in the theology of Scripture, objective principles would have justified ethical approaches. However, as a general conclusion regarding the preamble of this particular treaty, it may be stated that the epistemological meaningfulness of this covenant leaves much to be desired, since it is not embedded in a particular, presuppositional framework, thereby leaving it wide open to any and all subjective interpretations (Stackhouse \& Healy, 1996:487-488). This is also evident in the particulars of the articles some of which will now be critiqued in detail. 


\subsection{Article 1}

This article amplifies the covenantal preamble by wording the concept of freedom in the context of national identity, national governance and the disposal of economic resources. Section 1.1 states that all peoples have the right of self-determination. By virtue of that right they freely determine their political status and freely pursue their economic, social and cultural development.

The wording of this section (art. 1.1) begs many a question, e.g.: What are we to understand by "peoples"? Does "peoples" involve politically existing entities, commonly called "nations"? Does it mean particular cultural or racial groups? Are we talking here about tribes? This is not mere semantics; in recent political history, wars have been waged in terms of that question, as groups in the Balkans, notably in former Yugoslavia, have engaged in fierce combat to become independent, political regions. Kashmir is still a political thorn in two other nations' flesh. Cyprus is in a politically challenging situation, wishing to join the European Community, but not able to do so because of its division into a Greek and a Turkish area.

Therefore, if it were true that all peoples have a right to selfdetermination, then it would be extremely useful to define the concept with definitiveness prior to ratifying what seems currently a rather mystical statement. Were the covenant placed in the Biblical framework, then the connotations would be clear. First of all, Acts $17: 26$ informs us that the question of races is inconsequential; we are all one race, the human race, with common ancestry, with equal ontological dignity. According to the Scriptures, developing within this one race, peoples are made up of tribes, or federations of tribes. For instance, in the case of the ancient nation of Israel a federation of tribes formed a people, God's people, bonded in the common theocracy and ancestry, developing its own, identifiable culture over time.

The next question regarding this article would be what exactly the parameters of self-determination are. If it is the United Nations, collectively giving the seal of approval, this would ipso facto curtail full-orbed self-determination, since the United Nations is not likely to allow such a nation to determine its own future in every way without a measure of accountability to the collective. Nations such as Iraq and North Korea have felt this in terms of nuclear developments; Japan is seriously out of favour at present (anno 2005/2006) because of its disagreeable stand on whaling; the United States is considered to be in violation of human rights within the United 
Nations community because of the death penalty operational in various states; the same nation is being accused, at the Earth Summit II conference 1992 in Rio de Janeiro and at United Nations Climate Change conferences, of human rights violations for its socalled global warming emissions (Lamb, 2000:2-3). One writer goes as far as to declare that European businessmen/women and financial leaders recognise that the largely American-determined model of neo-liberal globalisation is leading to environmental and social disaster (George, 2002). The pressure to conform on nations which desire to run counter to party line, is enormous; this begs the question of self-determination.

The great concern of many a political observer is that globalisation runs counter to man's innate desire to identify with something higher than himself, but still near enough to visualise. Schlevogt signalises the phenomenon of employee alienation in a global market place and makes a convincing call for re-nationalisation: while managers have become globalists, many employees still remain locally rooted. Many employees want to relate to something, such as physical headquarters in their mother country, instead of a virtual dream castle. They may also want to serve a cause greater than themselves yet tangible, and the nation is arguably a better motivator in this respect than a global collective (Schlevogt, 2002).

It appears that the good desire expressed in the article regarding self-determination is countered by globalisation in almost every area imaginable. The "global village" concept is now accepted worldwide. Searching the term on the internet provided 925000 results. Yet, people need roots; they need identification with a place. The Māori people of New Zealand have a very telling way of expressing this: all their narratives are impregnated with the word turangawaewae, a place to stand, as being of fundamental importance for a man's identity and dignity; every formal speech is expected to start with declaring the speaker's turangawaewae. The sad thing is that, while this place to stand is in the process of being lost, recapture will be nigh impossible without a basis of presuppositional justification. This means that a unifying ethos must be found. This, however, is fraught with many difficulties, as already mentioned earlier.

Article 1.2 insists that all peoples may, for their own ends, freely dispose of their natural wealth and resources without prejudice to any obligations arising out of international economic cooperation, based upon the principle of mutual benefit, and international law. In no case may a people be deprived of its own means of subsistence. 
However, the disposal of natural wealth is very much subject to United Nations scrutiny nowadays; immense pressure is exerted to push the disposal one way or another, depending as to how economical analysts, along with the politicians who rely on them, on either the receiving or dispersing side, regard the economical balance of power. It appears that the idea of "free disposal" and "mutual benefit" constitutes a potential clash; a conflict waiting to happen. The two words, in a world without an unifying ethical framework, appear to be mutually exclusive.

Article 1.3 expresses the commitment that each State Party to the present Covenant has. Both individually and through international assistance and cooperation, especially economic and technical, each party is to be pro-active to the maximum of its available resources. It is to be done with a view to achieving progressively the full realisation of the rights recognised in the present Covenant by all appropriate means, including, particularly, the adoption of legislative measures.

"Full realisation" is difficult to calibrate, because this does not merely depend on the potential of mineral and other material resources, but it also depends - to an even greater extent probably - on the potential of the people who handle the resources. This concept begs once more a question of worldview calibre in terms of work ethics. In a worldview where work is not regarded as a blessing, but rather as a necessary evil, or - as it has been said about Australia and New Zealand - as a means to reach the next weekend of hedonistic pleasure (personal conversations - $\mathrm{HZ}$ ), the concept of full realisation is stymied by a limiting approach. In a Christian community, where work is approached as something to be done to the glory of God, in stewardship to the Lord and Master, where work means the deployment of god-given talents, this full realisation takes on different proportions, as shown many a time in history (Nickel, 1991). Realisation of rights is contingent on good understanding of duties (Novak, 1996:179-180).

\subsection{Article 2}

Article 2 commits member states to use all appropriate means to guarantee that the rights of the covenant will be exercised without discrimination of any kind as to race, colour, sex, language, religion, political or other opinion, national or social origin, property, birth or other status. 
The issue regarding appropriate means is difficult to find unified understanding on. In a Judeo-Christian concept, agreement may be arrived upon. In an Islamic or Communist understanding the expression may well be translated and applied differently (Stackhouse \& Healy, 1996:487-488). With the creation of the International Criminal Court, adopted in Rome in 1998, the door has been opened to the prosecution of those who violate human rights. This court has the authority to redefine its jurisdiction at will (formerly, violation of human rights was limited to war crimes, genocide, international terrorism, and such like - not without problems either), and may do so without regard to the United Nation Security Council (Lamb, 2000:2). Add to this the umbrella statement in the preamble of the United Nations Charter that "reasonable force may only be used in the common interest", and it appears that a potentially explosive situation has been created. The question must be asked who determines the appropriate means. If appropriate means result in force being used against a particular member in service to the common interest of all, inclusive of that member, agreement will be hard to find. Were the member and its sympathisers excluded, the appropriate means would be a matter of majority decision, leading to unacceptable paternalism on the part of such a majority over the minority. Without a presuppositional framework to operate within, equitable action may well be a challenge beyond the signatories' power.

\subsection{Other articles}

A summative impression of a number of other articles will provide further insight in the perceived problematic nature of this particular covenant.

In articles 9 through to 12 either the influence of Christian morality, or the truth of doctrine in the Canons of Dort (Article 4, third head: "There remains in natural man a glimmer of the imagebearing of God, restricting evil and promoting good"), or both may be detected. Article 9 and 10 make a case for the protection of the vulnerable in society, in acknowledging their right to basic economic sustenance, protection from inappropriate burdens (cf. child labour). This fits the Biblical dictum that true Christianity is exercised by expressing love to one's neighbour (cf. James 1:27). The tenor of Article 12 is in tune with protection of the sanctity of life which the Scriptures also emphasise (cf. Gen. 9:5). Problematic in terms of the Biblical role of the mother, as the one who nurses growing children at home, who is the homemaker, is the assumption underlying the phraseology in 
Article 10 , in declaring that mothers are out in the work force and therefore need their labour rights protected. Of course, equity in the labour force is right to maintain (cf. Prov. 13:11; 14:23; 1 Tim. 5:18), but the question for some will be whether the creation ordinance set in place by God is being honoured.

Article 10 and 13 appear to be in conflict; where Article 10 cedes the duty of educational care to the family, with the State protecting this duty, Article 13 places such duty of care plainly with the State authorities. Biblically speaking, Article 13 attributes to the State an obligation which, in terms of Biblical ethics, is not hers to exercise (Blumenfeld, 1985:219-220; Thoburn, 1986:62-77).

The notion of Article 25, that nothing in the present covenant shall be interpreted as impairing the inherent right of all peoples to enjoy and utilise fully and freely their natural wealth and resources, is in agreement with the nationhood set forth in Scripture (Vorster, 2004:42), However, this statement could raise problems when placed over against certain sections of Article 1, which limits nations in the free utilisation of natural wealth and resources by putting riders in the mix when declaring that all of this is to be exercised "to mutual benefit", "without depriving a people of its own means of subsistence", and "in conformity with provisions of the Charter of the United Nations". The absence of unifying ethics on which global covenants should be founded may well give rise to serious disputations.

\section{Conclusion}

The world community leaders express a noble desire towards the ensuring of human dignity in all societies everywhere. To that end, noble sentiments have been translated into statements to which member nations covenant themselves. However, these member nations all boast their own, unique cultures, religions, and consequently, worldview approaches. This makes the unified implementation of measures to ensure the protection of human dignity difficult. United approaches need to be founded on a homogenous, ethical framework (Stackhouse \& Healy, 1996:508512). The only ethical framework available to mankind is the Word of God, because only the Word of God holds the metaphysically implanted principles which provide the transcendent guide devoid of human subjectivism (Sproul, 2006:29-30).

If indeed Biblical ethics are the only ethics available to man (Sproul, 2006:29-30), then all other attempts at unification can only be 
subjective, human agreements. It is apparent, given the fact that members actually put their names to the covenant, that all agree at an esoteric level (Snook, 2005), with the desires expressed in the covenant. In keeping with the Canons of Dort (third and fourth heads of doctrine, Article 4) all confirm thereby the truth that "there remain, however, in man since the fall, the glimmerings of natural light, whereby he retains some knowledge of God, of natural things, of the difference between good and evil, and shows some regard for virtue and for good outward behaviour".

The theoretical agreement meets with difficulties when implementation is required. For then, all of a sudden, various members evidence varying understanding. If indeed everything is value-laden (Greene, 1990:72), then the question in need of an answer is which values are going to determine the applicatory consequences of the covenantal content. In a vast, global body such as the United Nations this presents difficulties which are very challenging.

A desire to do what is good shines through very clearly in the covenant under study. The desire to be a servant to the worldwide community in promoting human dignity is clearly underwritten and is laudable. Recognition of this must lead to a careful approach when critiquing a work of this nature. The implied desire to work toward the restitution and preservation of human dignity will be lauded by God Himself; e.g. Psalm 116:15 declares how precious the souls of his saints are, many of whom live in areas of the world that are destitute and in need of help, and Galatians 6:10 exhorts goodness toward all men. Believers are encouraged to be good to all men, first of all, because all men are created in the image of God, and secondly, among all those we meet, but do not recognise as Christians, may well be "lost sheep to the house of Israel" (John 10:16).

Nevertheless, from the Biblical worldview perspective, the question needs to be asked once again what the dignity mentioned in the covenant is based on. Deconstructive discourse permits subjective opinion to determine this. Observers at United Nations proceedings claim to detect a clearly socialist, anti-Biblical agenda (Yates, 2004: Part 4-7). The Movement Freedom21, which strives to advance the principles of freedom in the 21st century, is very strongly critical of the work of the United Nations in its perceived drive for world government (Yates et al., 2005). Subsequent documents to the one under discussion, lead to serious questions as to which agenda determines the tone of all the humane-sounding phrases. 
One such document is the United Nation's 1981 Declaration on the Elimination of all Forms of Intolerance and of Discrimination Based on Religion or Belief. A particular author, in addressing the debate on hate laws in South Africa and referring to Articles 2 and 3 of this declaration as being central to the debate, says that this is a typically schizophrenic document in that it grants the "right to freedom of thought, conscience, religion, or whatever belief", yet at the same time demands that "any distinction, exclusion, restriction or preference based on religion or belief ... constitutes an affront to human dignity ..." and is an "obstacle to peaceful relations between nations" (Scarborough, 2005:1). Currently, in the State of Victoria, Australia, two pastors are incriminated for hate speech against Muslims, simply by declaring the Word of God. Considering the fact that the 1981 document effectively presents a further detailing of what is contained in the covenant being studied here, the tenet and thrust of the package causes difficulty for those who hold to fundamental beliefs.

G.K Chesterton once said, "Tolerance is the virtue of a man without conviction" (Baucham, 2004), and the thought of a society determined by indeterminate covenants ought to be cause for concern (Reid, 2002). In United Nations membership countries, this problem tends to lead to marginalising and even the banning of those who hold firmly to objective truth. This is observed in New Zealand (McGrail, 2004), in Australia (Simpson, 2005), and in South Africa (Scarborough, 2005:1).

In this universal "brotherhood of man" climate, in which all ideologies are to be equally acceptable, for which a unifying ethos is being sought, debate regarding translating global covenants into practice will may well continue to be fraught with tension.

The proposed solution here runs counter to the world government trend. In keeping with sentiments expressed by one author (Schlevogt, 2002), an obvious axiom to observe is that the parties engaged in a contract ought to do so in mutual respect regarding presuppositions. This means that commonality in worldview between them will be enabling, because only then can words, phrases and concepts be understood in a harmonious fashion. The United Nations members do not have this ethical unity.

Following from this observation, the next advisable step could be decentralisation. When this particular move was once proposed by a study committee of education in New Zealand, the members of the committee received death threats for daring to subtract from central 
State power (Picot Report, 1988); the resultant guide document (Tomorrow's Schools, 1989) essentially only allowed decentralisation for Māori education, with reduced funding for this group. Decentralisation runs counter to the world political scene. The wider political bodies are growing; even the fiercely independent nation of Switzerland has joint the United Nations in 2002, though it, paradoxically, has not sought membership to the European Union. Australia has, under economic pressure, conceded to sign a nonaggression pact with the Asian nations in order to gain entry to Asean (Taylor, 2005).

Unity in worldview and decentralisation go hand-in-glove. Nations could lend mutual support in the atmosphere of true mutual respect and understanding. However, the role of the United Nations would necessarily be reduced to that of a - for want of a better word news exchange forum and ombudsman, where nations could report and encourage each other, where nations could seek out partnerships for economic and other support, but now without coercive pressure of mondial expectations. Such an approach would most closely resemble the Biblical example of individual nations entering into covenant (Douglas et al., 1982:240-241), and would encourage the most likely probability of success, always realising that perfection will not be found in our fallen world.

Should Christians withdraw from an organisation which has so many marks of other, even contrary, worldviews features in driving politics? The Christians in ancient Rome answered this affirmatively, retracting from politics and all manners of social contact. Such world-flight is not Biblical. While the world continues to exist in its present form, Christians are called upon to be salt and light, i.e. healing and direction-giving (Matt. 5:13-14). By all means, Christians should take part, should not boycott by absence, but all the while they should demonstrate the discernment of the tribe of Issachar (1 Chron. 12:32), recognise varying ethical approaches and strive for Biblical ethics.

\section{List of references}

AN-NA'IM, A.A. 1996. Islamic foundations of religious human rights. (In Religious human rights in global perspective. The Hague: Nijhoff.)

ANON. 1945. Charter of the United Nations. http://www.un.org/aboutun/charter/ Date of access: 17 May 2006.

ANON. 2005. Charter of the United Nations. http://www.en.wikipedia.org/ Date of access: 16 July 2005.

BAILLIE, J., MCNEILL, J.T. \& VAN DUSEN, H.P. 1979. Calvin: Institutes of the Christian religion II. Philadelphia: The Westminster Press. 
BAUCHHAM, V. 2004. The ever-loving truth. Nashville: Broadman \& Holman.

BLUMENFELD, S.L. 1985. Is public education necessary? Boise: The Paradigm.

DOUGLAS, J.D., HILLYER, N., BRUCE, F.F., GUTHRIE, D., MILLARD, A.R., PACKER, J.I. \& WISEMAN, D.J. 1982. New Bible Dictionary. Leicester: InterVarsity.

GEORGE, S. 2002. Who holds the reins of power in the global economy? European business forum: 22June.

GREENE, A. 1990. Thinking Christianly. Medina: Alta Vista College.

GRESHAM MACHEN, J. 1982. God transcendent. Edinburgh: Banner of Truth.

HERMAN, R. 1992. When the "Father" is a sperm donor. Washington Post: 11, Feb.

HONEYSETT, M. 2002. Meltdown - making sense of a culture in crisis. Leicester: InterVarsity.

KIMBRELL, A. 1993. The human body shop. San Francisco: Harper Collins Religious.

LAMB, H. 2000. Senate ratifies Desertification Treaty, 33 others. Washington: Eco-Logic.

MARIN-GUZMAN, R. 2003. Fanaticism: a major obstacle in the Muslim Christian dialogue: the case of twentieth century Muslim fundamentalism. Arab Studies Quarterly.

MARTY, M.E. 1996. Religious dimensions of human rights. (In Religious human rights in global perspective. The Hague: Nijhoff.)

MCCARTHY, D.J. 1978. Treaty and covenant. Rome: Biblical Institute.

MCGRAIL, A. 2004. The changing face of tolerance. Kaitaia: Northland Age.

NICKEL, J. 1991. A Biblical view of work. (In Zandman, H.J.G., ed. New Zealand Association for Christian Schools Conference on Christian Education. Masterton: New Zealand Association for Christian Schools.)

NOVAK, D. 1996. Religious human rights in Judaic texts. (In Religious human rights in global perspective. The Hague: Nijhoff.)

PALMER ROBERTSON, O. 1980. The Christ of the covenants. Phillipsburg: Presbyterian \& Reformed Publishing.

REID, M. 2002. Tolerance and inclusion cause problems. Otago Daily Times.

SCHLEVOGT, K.A. 2002. Why multi-nationals should re-nationalise. London: Caspian Publishing. European Business Forum 22 June.

SIMPSON, N. 2005. Victoria defends controversial law. (In Colvin, M., ed. PM Radio Current Affairs. Ultimo.)

SNOOK, I. 2005. Summary address. (In Values education. Canberra: Department of Education Australia.)

SPROUL, D.C. 2006. The basis of ethics. Tabletalk, 30:29-30.

STACKHOUSE, M. \& HEALY, S.E. 1996. Religin and human rights: a theological apologetic. (In: Religious human rights in global perspective. The Hague: Nijhoff.)

TAYLOR, R. 2005. Australia signs friendship pact pledge. (In The Australian. Sydney.)

THOBURN, R.L. 1986. The children trap. Fort Worth: Dominion.

TUTU, M.D. 1996. Preface. (In Religious human rights in global perspective. The Hague: Nijhoff.)

VORSTER, J.M. 2004. Ethical perspectives on human rights. Potchefstroom: Potchefstroom Theological Publications.

VORSTER, J.M. 2005. Personal conversations. Geneva. 
WADUD, A. 2002. A'ishah's legacy: Amina Wadud looks at the struggle for women's rights within Islam. New Internationalist Magazine: 5, Jan.

WEEKS, N. 2005. Reflected light: essays in Christian social policy. Sydney: Westminster Presbyterian Church of Australia.

YATES, S. 2004. The real matrix. http://www.newswithviews.com/Yates/ steven6.htm Date of access: 27 Jul. 2004.

\section{Key concepts:}

Christians: called to be salt and light covenant: ethical framework

Scriptures: principles for engaging into covenants

United Nations: multiplicity of worldviews

\section{Kernbegrippe:}

Bybel: beginsels vir verbondsluiting

Christene: geroepe om sout en lig te wees

verbond: etiese raamwerk

Verenigde Volke: veelvoudige wêreldbeskouings 